\author{
AMERICAN JOURNAL OF FOOD AND NUTRITION \\ Print: ISSN 2157-0167, Online: ISSN 2157-1317, doi:10.5251/ajfn.2012.2.1.26.30 \\ (C) 2012, ScienceHu $\beta$, http://www.scihub.org/AJFN
}

\title{
Effect of processing methods on the nutritional contents of bitter leaf (Vernonia amygdalina)
}

\author{
Yakubu, N., Amuzat, A.O. and Hamza, R. U. \\ Department of Biochemistry, IBB University, Lapai. \\ Niger State, Nigeria.
}

\begin{abstract}
This study was conducted to determine the effect of four different processing methods on the nutritional contents of bitter leaf (Vernonia amygdalia). Fresh bitter leaves were subjected to different conventional food processing techniques, namely soaking in water (over night), blanching, abrasion with salt and without salt (Nacl) as well as fresh leave samples replicated three times. The fresh and treated samples were analyzed for antioxidant properties (reducing power and free radical scavenging ability), proximate compositions, mineral contents and antinutrient contents (tannin and phytate). The results obtained revealed that the reducing power of bitter leaf $(0.53)$ was significant decreased with all the processing methods in the study. The free radical scavenging ability of fresh bitter leaf sample (70\%) was significantly higher than in other treated samples (53-57\%).The protein $(6.0-7.3 \%)$ and moisture contents $(81.5-84.0 \%)$ of variously treated bitter leaf were significantly $(p \leq 0.05)$ lower than that of fresh leaves $(8.4 \%)$ and $(84.4 \%)$ respectively. Similarly, there was a decrease in the fat content by blanching and abrasion without salt $1.0 \%$ and $0.9 \%$ respectively, while soaking and abrasion with salt was increased by $2.2 \%$ and $2.3 \%$ respectively. The crude fiber content was lower with soaking while it was significantly $(p \leq 0.05)$ higher with abrasion with salt. Blanching and soaking caused a significant $(p \leq 0.05)$ decreased in the ash content while abrasions elevated its contents. Also, the various processing methods caused a significant reduction in mineral content of vegetable. The tannin content of $v$. amygdalina leaf $(0.6 \%)$ was significantly $(p \leq 0.05)$ reduced by the various treatments $(0.4-0.5 \%)$. Similar trend was observed for phytate content with the exception of the soaked sample which showed no decrease. It could therefore be concluded that soaking overnight and blanching caused a significant reduction in the nutritional values of bitter leaf than other processing methods studied.
\end{abstract}

Key words: Nutrition, processing methods and Vernonia amygdalina

\section{INTRODUCTION}

One of the basic needs of man is the provision of sufficiently and nutritionally adequate food. The National food Security Agency aims at providing food in adequate quantity and quality to keep the pace with increasing population. However, the tremendous post harvest treatments resulted in unequal food quality (Oboh, 2003. The nation is now be coming aware of importance of food security as an effective tool in increasing food quality (Edward,2001).

Vernonia amygdalina (Bitter leaf) is a shrub or small tree of 2-5 meters, which grows under a range of ecological zones in Africa and produces large mass of forage and is drought resistant. The leaves are green with a characteristic odor and a bitter taste (Bonsei etal.,2001). Bitter leaves are used for human and animal consumption. For human consumption it is washed to get rid of the bitter taste and used as vegetables. It stimulates the digestive system as well as help to reduce fever. They are also used as local medicine or herb against parasites. The plant is well known for its antidiabetic and antihypertensive properties, and also used in the treatment of headache and fever (Oboh,2003). A preliminary phytochemical screening of bitter leaf indicated the presence of saponins, tannins, terpenes, alkaloids and steroid (Igile et al.,1995). The better taste of bitter leaf is due to antinutritional factors such as alkaloids, saponins and tannins (Oboh, 2005). The leaves of bitter leaf are bitter; however after soaking the leaves in water and cooking, local people use it in soup and stew as a strength given tonic. The boiling and cooking has been found to reduce secondary plant compounds and makes the feed more palatable (Oboh,2005). The leaves of bitter leaf are very bitter 
because of the presence of secondary plant products and antinutritional factors. The leaves are therefore treated by washing and cooking before eating as soup and medicine. It is therefore of importance to consider the effect of these treatments on the nutritional properties of the better leaf. The objective of the study was to investigate the effect of some processing methods on the antioxidant properties, proximate compositions, mineral contents and antinutrient contents of bitter leaf.

\section{MATERIALS AND METHODS}

Source of materials: The bitter leaf used was obtained from the family garden located at Mokwa, Niger State. The leaves were identified in the Biological Unit, Niger State College of Agriculture, Mokwa. The chemicals used were analytical grades, while the water used was glass distilled water. The trial however was conducted in the Laboratory of Pest Management Technology Department, Niger State College Agriculture, Mokwa.

Sample Preparation; The fresh bitter leaves collected were rinsed in water and then edible portions were separated from the inedible portions. The edible portions were subjected to different treatments, namely soaking (overnight), blanching, abrasion with and without salt (Nacl) and then, ready for further analysis.

Methods: The nutrient compositions (ash, fat, moisture, carbohydrate, protein and crude fibre) of the treated samples were determined using the standard method of AOAC (1990). The $\mathrm{Zn}, \mathrm{Ca}, \mathrm{Fe}$, $\mathrm{Mg}, \mathrm{K}$ and $\mathrm{Na}$ contents were determined using atomic absorption spectrophotometry method of analysis described by A.O.A.C. (1990). The aqueous extracts of leaves were prepared for antioxidant property determinations (i.e. free radical scavenging ability of vegetable against DPPH (1,1-dipheny -2 picryl hydrazyl) free radical was used as described by Ursini et al., (1994) and the method described by Pulido et al., (2000) which was based on the ability of the vegetable to reduce $\mathrm{Fecl}_{3}$ was used to assessed reducing power of the vegetable ). The method described by Makker et al., (1993) was used for tannin content determination. Wheeler and Ferrel, (1974) method, which based on the ability of standard ferric chloride to precipitate phytate in dilute $\mathrm{Hcl}$ extracts of the vegetable was used.

Analysis of data: The data collected were presented as mean of three replicate. One way analysis of variance (ANOVA) and Least Significant difference
(LSD) was applied. Significance was accepted at $\mathrm{p}<0.05$ probability. (Zar, 1984).

\section{RESULTS:}

The result of proximate composition expressed in percentages of treated and untreated leaves of bitter leaf is presented in the table 1 . The result revealed that the fresh bitter leaves had higher moisture $(84.4 \%)$ and protein $(7.9 \%)$ values when compared with other food processing techniques evaluated in the study at ( $p \leq 0.05)$. The various conventional food processing techniques caused a significant decrease $(p \leq 0.05)$ in protein values, ranged between (84.0 $81.5 . \%)$ for moisture and $(7.5-6.0 \%)$ for protein contents. Other results are presented in table 1.

Table 1; Proximate analysis of fresh and treated bitter leaves (Vernonia amygdalina).

\begin{tabular}{|l|c|c|c|c|c|}
\hline Sample (\%) & Moisture & Protein & Fat & $\begin{array}{c}\text { Crude } \\
\text { fiber }\end{array}$ & Ash \\
\hline Fresh & $84.4^{\mathrm{a}}$ & $7.9^{\mathrm{a}}$ & $2.3^{\mathrm{a}}$ & $2.3^{\mathrm{a}}$ & $2.8^{\mathrm{a}}$ \\
\hline Blanched & $81.5^{\mathrm{b}}$ & $6.0^{\mathrm{C}}$ & $1.0^{\mathrm{b}}$ & $2.2^{\mathrm{b}}$ & $1.8^{\mathrm{c}}$ \\
\hline $\begin{array}{l}\text { Soaked(over } \\
\text { night) }\end{array}$ & $82.6^{\mathrm{b}}$ & $6.3^{\mathrm{c}}$ & $2.2 \mathrm{a}$ & $2.3^{\mathrm{a}}$ & $2.0^{\mathrm{b}}$ \\
\hline $\begin{array}{l}\text { Abrased } \\
\text { with salt }\end{array}$ & $84.0^{\mathrm{b}}$ & $7.5^{\mathrm{D}}$ & $2.3^{\mathrm{a}}$ & $2.3^{\mathrm{a}}$ & $2.8^{\mathrm{a}}$ \\
\hline $\begin{array}{l}\text { Abrased } \\
\text { without salt }\end{array}$ & $82.0^{\mathrm{a}}$ & $7.0^{\mathrm{b}}$ & $2.2^{\mathrm{a}}$ & $2.3^{\mathrm{a}}$ & $2.5^{\mathrm{b}}$ \\
\hline
\end{tabular}

Means with the same superscript letter(s) along the same column are not significantly different $(p \leq 0.05)$

The result of mineral compositions of treated and untreated bitter leaves is shown in table 2. It revealed that the fresh (untreated) bitter leaves had higher $\mathrm{Na}$ $(199.6 \mathrm{mg} / \mathrm{kg}), \quad \mathrm{Mg}(195.2 \mathrm{mg} / \mathrm{kg}), \quad \mathrm{Ca}(190 \mathrm{mg} / \mathrm{kg})$, $\mathrm{Fe}(17.4 \mathrm{mg} / \mathrm{kg}), \quad \mathrm{Zn}(9.0 \mathrm{mg} / \mathrm{kg})$ and $\mathrm{K}(177.1 \mathrm{mg} / \mathrm{kg})$. However, the various convectional food processed techniques reduced the content of the minerals, for iron(Fe), the sample abrased without salt had the highest $(17.3 \mathrm{mg} / \mathrm{kg})$, followed by abrased with salt $(14.5 \mathrm{mg} / \mathrm{kg})$ while blanched samples had a value of $12.2 \mathrm{mg} / \mathrm{kg}$ as iron content. Other results of mineral compositions are also shown in the table 2. Also the result of antioxidant determination of the treated and untreated (fresh) bitter leaves is shown in table 3 . The results indicated that the reducing property of untreated (fresh) bitter leaf had a value of 0.53 absorbance, blanched sample had 0.46 absorbance, soaked samples 0.51 absorbance, sample abrased with salt had 0.44 absorbance and sample abrased without salt had 0.50 absorbance. Table 4 showed the free radical scavenging ability $(70 \%)$ for fresh, blanched $(54 \%)$, soaked $(53 \%)$, samples abrased with salt $(57 \%)$ and sample abrased without salt 
(56\%). The result of anti- nutrient (tannin and phytate) contents is shown in table 4 . The result revealed that the fresh leaves had a tannin content of $(0.6 \%)$ and phytate content of $169.2 \mathrm{mg} / 100 \mathrm{~g}$. The food processed technique reduced the tannin content $(0.4 \%)$. The samples abrased with and without salt had a value of $0.5 \%$. The phytate content was not affected by soaking.

Table 2: Mineral composition of treated and untreated bitter leaves.

\begin{tabular}{|c|c|c|c|c|c|c|}
\hline Sample(kg) & $\mathrm{Fe}(\mathrm{mg} / \mathrm{kg})$ & $\mathrm{Zn}(\mathrm{mg} / \mathrm{kg})$ & $\mathrm{Ca}(\mathrm{mg} / \mathrm{kg})$ & $\mathrm{Mg}(\mathrm{mg} / \mathrm{kg})$ & $\mathrm{K}(\mathrm{mg} / \mathrm{kg})$ & $\mathrm{Na}(\mathrm{mg} / \mathrm{kg})$ \\
\hline Fresh & $17.4^{\mathrm{a}}$ & $9.0^{a}$ & $190^{\mathrm{a}}$ & $195.2^{a}$ & $177.2^{\mathrm{a}}$ & $199.6^{a}$ \\
\hline Blanched & $12.2^{c}$ & $4.2^{\mathrm{C}}$ & $115.1^{\mathrm{C}}$ & $116.6^{\mathrm{d}}$ & $154.4^{b}$ & $106.7^{\mathrm{C}}$ \\
\hline \multicolumn{7}{|l|}{ Soaked } \\
\hline overnight & $14.2^{b}$ & $5.6^{b}$ & $178.4^{b}$ & $141.8^{b}$ & $156.4^{\mathrm{C}}$ & $127.8^{\mathrm{C}}$ \\
\hline \multicolumn{7}{|l|}{ Abrased } \\
\hline with salt & $14.5^{b}$ & $5.6^{b}$ & $182.1^{\mathrm{a}}$ & $146.3^{b}$ & $157.7^{\mathrm{C}}$ & $166.3^{b}$ \\
\hline \multicolumn{7}{|l|}{ Abrased } \\
\hline without salt & $17.3^{\mathrm{a}}$ & $8.0^{a}$ & $184.3^{b}$ & $149.0^{b}$ & $184.4^{\mathrm{a}}$ & $160.3^{b}$ \\
\hline
\end{tabular}

Means with same superscript letter(s) within the same column are not significantly different $(P \leq 0.05)$.

Table3: The antioxidant properties of treated and untreated bitter leaves.

\begin{tabular}{|l|c|c|}
\hline Sample & $\begin{array}{c}\text { Reducing } \\
\text { property } \\
(\text { OD=700) }\end{array}$ & $\begin{array}{c}\text { Free radical } \\
\text { scavenging ability } \\
(\%)\end{array}$ \\
\hline Fresh & $0.53^{\mathrm{a}}$ & $70^{\mathrm{a}}$ \\
\hline Blanched & $0.46^{\mathrm{C}}$ & $54^{\mathrm{C}}$ \\
\hline $\begin{array}{l}\text { Soaked } \\
\text { overnight }\end{array}$ & $0.51^{\mathrm{a}}$ & $53^{\mathrm{C}}$ \\
\hline $\begin{array}{l}\text { Abrased } \\
\text { with salt }\end{array}$ & $0.44^{\mathrm{c}}$ & $57^{\mathrm{b}}$ \\
\hline $\begin{array}{l}\text { Abrased } \\
\text { without salt }\end{array}$ & $0.50^{\mathrm{b}}$ & $56^{\mathrm{b}}$ \\
\hline
\end{tabular}

Means with the same superscript letter(s) within the same column are not significantly different $(p \leq 0.05)$.

Table 4: Anti-nutrient content of treated and untreated bitter leaf

\begin{tabular}{|l|l|l|}
\hline Sample & Tannin (\%) & $\begin{array}{l}\text { Phytate } \\
(\mathbf{m g} / \mathbf{1 0 0 g})\end{array}$ \\
\hline Fresh & $0.6^{\mathrm{a}}$ & $169.2^{\mathrm{a}}$ \\
\hline Blanched & $0.4^{\mathrm{C}}$ & $112.8^{\mathrm{b}}$ \\
\hline Soaked overnight & $0.4^{\mathrm{c}}$ & $169.2^{\mathrm{a}}$ \\
\hline Abrased with salt & $0.5^{\mathrm{b}}$ & $112.8^{\mathrm{b}}$ \\
\hline Abrased without salt & $0.5^{\mathrm{b}}$ & $102.4^{\mathrm{C}}$ \\
\hline
\end{tabular}

Means with the same superscript letter(s) within the same column are not significantly different $(p \leq 0.05)$.

\section{DISCUSSION}

Table 1 showed the results of proximate composition of the treated, untreated bitter leaves and revealed that the fresh (untreated) leaves had $7.9 \%$ protein. However, the various convectional food processed techniques caused a significant decreased $(p \leq 0.05)$ in the crude protein content while the sample that was blanched had the greatest decrease. The decreased in protein content by the various treatments could be attributed to the fact that some of the proteins were leached off by water during soaking and blanching (Oboh,2005). The crude protein content for both treated and untreated leaves of bitter leaf were higher than the reported values for $S$. melogena leaf $(4.66 \%)$, S.acthiopecum leaf $(4.8 \%)$, S. lycopersium leaf (2.8\%) and S. nigram leaf (3.2\%) (Oboh and Akinahunsi, 2004).Also, the various convectional food processed methods brought a significant $(p \leq 0.05)$ decreased in the moisture content. The sample abrased with salt had the highest moisture content when compared with other processed samples in the study. The fat content was only affected much by the blanching and showed a significant decreased $(p \leq 0.05)$. The ash and crude fiber contents of samples abrased with salt were higher compared with other processed samples evaluated in the study. Table 2 showed the result of mineral contents which revealed that $\mathrm{Zn}(9.0 \mathrm{mg} / \mathrm{kg})$, Fe $(17.4 \mathrm{mg} / \mathrm{kg}), \mathrm{Ca}(190 \mathrm{mg} / \mathrm{kg}), \mathrm{Mg}(195.2 \mathrm{mg} / \mathrm{kg}), \mathrm{K}$ $(177.1 \mathrm{mg} / \mathrm{kg})$ and $\mathrm{Na}(199.6 \mathrm{mg} / \mathrm{kg})$ were high in fresh (untreated) bitter leaf. These findings are in accordance with a report that green leafy vegetables are good sources of dietary minerals (Akindahunsi andOboh,1999). However, all processing of the leaves caused significant decreased $(p \leq 0.05)$ in all the minerals analyzed. These findings agreed with earlier reports by Akindahunsi and Oboh (1999) that abrasion, blanching and soaking may cause a 
significant decreased in the mineral composition of leafy vegetables. The antioxidant properties (reducing property and free radical scavenging activity) of both treated and untreated bitter leafy is shown in table 3 . It revealed that there was a significant decreased $(p \leq 0.05)$ in the reducing property of blanched sample (0.46) and abrased with salt $(0.44)$ compare with the fresh (untreated) leaves (0.53). This decreased in reducing property indicates that most of the phytochemical constituent that would have furnished the needed hydrogen would have been leached off during blanching and abrasion. However, samples soaked overnight and abrased without salt showed slight decrease in reducing power but, the sample soaked overnight having the highest reducing power (0.51). Also, result showed significant reduction $(p \leq 0.05)$ in free radical scavenging ability of all the treated sample compared to the untreated samples of bitter leaf. The blanched and soaked overnight samples had the lowest free radical scavenging activity. The result indicated that free radical scavenging ability of all the treated samples ranged from $53 \%-57 \%$. This values were within the same range with that of Oboh, (2005) for some tropical vegetables. This agreed with the earlier report by Oboh, (2005) that blanching for $5 \mathrm{~min}$. cause a significant $(p \leq 0.05)$ decreased in vitamin $C$ content, reducing power and free radical scavenging ability of eight popularly consumed green leafy vegetables in Nigeria. Table 4; showed the result of antinutrient contents of treated and untreated bitter leaf. Tannins, which are phenolic of higher molecular weight containing sufficient hydroxyls and other suitable groups (ie carboxyls) to form effectively strong complexes with protein, starch and minerals making them nutritionally unavailable (Harbone, 1989). There was a significant decrease in the tannin content of the treated leaves $(0.5-0.4 \%)$ when compared to that of fresh bitter leaf $(0.6 \%)$. Blanching and soaking caused the highest decrease in the tannin content $(0.4 \%$ in each case). This suggests that blanching and soaking will be a very good method of reducing the tannin content in $v$. amygdalina leaves. Phytic acid though considered an anti nutritional factor is a common storage form of phosphorus in seed and in a few tubers and fruits (Oboh, 2005). The complexing of phytic acid with nutritionally essential minerals and possibility of interference with proteolytic digestion have been suggested as responsible for the anti nutritional activity. Phytic acid interferes with $\mathrm{Ca}, \mathrm{Fe}, \mathrm{Mg}$, and $\mathrm{Zn}$ absorption because of it ability to chalate divalent cationic minerals (Nelson et al.,1968). As shown in table 4 , the phytate content of the fresh leaves is $169.2 \mathrm{mg} / \mathrm{g}$. The various treatments brought a significant change in the bitter leaves phytate content. This is inline with the report that various food processed technique can cause a reduction in phytate content of plant foods (Akindahunsi and Oboh, 1999). Of all the food processing techniques used in this experiment, abrasion causes the highest decrease in the phytate content of bitter leaves.

\section{CONCLUSION:}

The study revealed that the various food processing techniques, namely blanching, soaking, abrasion with and without salt would significantly reduce the nutrient, mineral, anti nutrient contents and the antioxidant properties of bitter leaf. However, blanching and abrasion lowered the antinutrient content when compared with other methods. Therefore, all the food processing techniques used had negative effect on the nutrient, mineral and the antioxidant property of the vegetable leaves, but blanching and abrasion were the best ways of reducing the antinutrient content of the vegetable leaves.

\section{RECOMMENDATIONS:}

The leaves of bitter leaf contained important nutrients and minerals which are good for the body. Hence, due to its high bitter taste, the above named food processing techniques have to be applied before taken by man but, has to be coupled with nutrient supplements because of the effects of these methods on the nutritional composition. Abrasion with salt on the overall appears to be the best method that maintained and conserved nutrients composition and also, blanching and abrasion were of best methods of reducing the antinutritional factors of bitter leaf. Further research is recommended in this area to find out the effect of these treatments on the toxicological properties of Vernonia amygdalina (bitter leaf).

\section{REFERENCES}

Akindahunsi,A.A. and Oboh, G; (1999): Effect of some post harvest treatments on the bioavailability of Zinc from some selected tropical vegetables. La Rivista Italian a Della Grasse 76, 285-287.

A. O. A. C; (1990): Official methods of Analysis of the Association of Official Analytical Chemist, $12^{\text {th }} \mathrm{ed}$. Washington DC. Pp 22-23.

.Edward,C.C; (2001): Food intake of Nigeria workers. A review and recommendations for improvement. J. of Nutrition Science 1(2). 178-184. 
Harbone,J.B. (1989) Biosynthesis and function of anti nutritional factors in plants, Aspect of Applied Biology 19: pp. $21-28$.

Igile,G.O; Oleszek, W.J.M; Aquino,R; (1995): Vernonisides $D$ and $E$, two novel saponins from Vernonia amygdalina. J. National production, 58(a) 438-1443.

Makker, H.P.S;Blummel, M; Bowwy, N.K and Beeken, K. (1993) Determination of Tannins and their Correlation with chemical and protein precipitation method. Journal of science, food and agriculture, 61:161 185.

Nelson, K; Takagi, A; Umemura,T; Hasagawa,R. and Kurokawa, Y; (1968): Toxicology, J. Environmental pathology Orcol; 11; 139-143

Oboh,G; (2003): Hemolytic effect of saponin extract from vernonia amygdalina (bitter leaf) on human erythrocyte. Applied Natural Science Research. 1(14); 25-29

.Oboh, G and Akindahunsi, A.A (2004) Effect of blanching and soaking on the antioxidant properties of some tropical green leafy vegetables, Biochem. Dept; Federal University of Technology, P.M.B. 704. Akure, Nigeria. Ondo State..

Oboh,G; (2005): Effect of blanching on the antioxidant property pf some tropical green leafy vegetables, Leborism, Wiss. U-Technol 38(5): 513-517.

Pulido, R; Bravo, L; and Saura -Calixo,F. (2000) Antioxidant activity of chetary polyphenols as determined by a modified ferric reducing/antioxidant power assay. Journal of agriculture and food chemistry; 48, $3396-3402$.

Ursini, M.M; Morazzoni,P; Rovevi,A and Pifferi, G. (1994) A novel antioxidant (idB1031) affecting molecular mechanism of cellular, free radical biology and mechane, 16, PP. $547-553$.

Wheeler, E.L and Ferrel, R.E. (1974) A method for phytic acid determination in wheat fractions cereal chemistry 48, 312-316.

Zar. J.I.I; (1984): Biostatistical Analysis, USA. Prentice-Hall. 